\title{
PENGGUNAAN METODE DISKUSI DARING UNTUK MENINGKATKAN HASIL BELAJAR BAHASA INDONESIA
}

\author{
TUKINAH \\ SD Negeri 011 Titian Resak \\ e-mail: tukinah@guru.sd.belajar.id
}

\begin{abstract}
ABSTRAK
Dalam masa pandemi ini mengharuskan dilaksanakannya pembelajaran jarak jauh menggunakan aplikasi virtual. Hal ini menyebabkan berkurangnya komunikasi antar siswa, hilngnya kedekatan siswa dan guru, hingga tidak tersampaikannya materi secara merata. Salah satu imbasnya juga berkurangnya pemahaman siswa terhadap materi Bahasa Indonesia, padahal Bahasa Indonesia merupakan jembatan untuk mata pelajaran lain, dalam kehidupan sosial, bahkan berkomunikasi dengan diri sendiri. Untuk itu penulis melakukan penelitian terkait metode diskusi untuk meningkatkan kemampuan Bahasa Indonesia siswa. Metode diskusi memiliki beberapa keunggulan dan manfaat seperti mempererat hubungan murid dan guru tetapi dapat beresiko perkelahian dan kesenjangan hubungan antar siswa di luar jam pelajaran, kemudian membuat siswa mampu berpikir kritis terhadap suatu informasi yang didapatkan tetapi dapat beresiko membuat beberapa siswa saja yang mendominasi diskusi, selain itu juga dapat membuat waktu pelajaran tidak membosankan tetapi adanya kemungkinan bahwa menyita banyak jam pelajaran atau bahkan tidak terselesaikannya diskusi, dll. Setelah melakukan analisis diketahui bahwa variabel berdistribusi normal sehingga metode uji perbandingan yang dapat digunakan adalah menggunakan uji paired t test, hasil dari uji ini adalah dapatkan nilai $p$-value untuk menolak hipotesis null sebesar $5.135 \times 10^{-7}$ yang mengartikan bahwa adanya perbedaan nilai siswa sebelum dan setelah dilakukannya metode diskusi, di mana nilai pembelajaran dengan metode diskusi lebih baik dikarenakan rata-rata yang lebih tinggi yaitu sebesar 77.25.
\end{abstract}

Kata Kunci: Metode Diskusi, Siswa, Bahasa Indonesia.

\section{ABSTRACT}

During this pandemic, distance learning is required using virtual applications. This results in reduced communication between students, the loss of closeness between students and teachers, so that the material is not conveyed evenly. One of the impacts is also the decrease in students understanding of the Indonesian language material, even though Indonesian is a bridge for other subjects, in social life, and even communicating with oneself. For this reason, the authors conducted research related to discussion methods to improve students' Indonesian language skills. The discussion method has several advantages and benefits such as strengthening student-teacher relationships but can be at risk of fights and relationship gaps between students outside of class hours, then makes students able to think critically about an information obtained but can risk making only a few students dominate the discussion, in addition to it can also make class time less boring but there is a possibility that it takes up a lot of class hours or even discussions are not finished, etc. After conducting the analysis, it is known that the variables are normally distributed so that the comparison test method that can be used is to use the paired $t$ test, the result of this test is to get a p-value to reject the null hypothesis of 5.135x10-7 which means that there are differences in student scores before and after after the discussion method was carried out, where the value of learning with the discussion method was better due to a higher average of 77.25.

Keywords: Discussion Method, Student, Indonesian.

\section{PENDAHULUAN}

Bahasa memiliki peran yang sangat penting dalam perkembangan intelektual, sosial, dan emosional peserta didik yang juga merupakan penunjang keberhasilan dalam mempelajari 
semua bidang studi. Bahasa adalah alat komunikasi antaranggota masyarakat berupa lambang bunyi yang dihasilkan oleh alat ucap manusia. Bahasa Negara Indonesia sendiri adalah Bahasa Indonesia. Mulai dari kegiatan sehari-hari hingga kegiatan pembelajaran menggunakan Bahasa Indonesia, oleh karena itu bahasa sangat penting dalam penunjang kehidupan. Pembelajaran bahasa Indonesia sendiri diarahkan untuk meningkatkan kemampuan peserta didik dalam berkomunikasi dengan baik dan benar, baik secara lisan maupun tulisan, serta menumbuhkan apresiasi terhadap hasil karya kesastraan manusia Indonesia.

Pada masa pandemi yang mengharuskan segala kegiatan pembelajaran dilakukan secara dalam jaringan berimbas pada kurangnya atau terbatasnya komunikasi baik siswa dengan siswa atau siswa dengan guru, hal ini menyebabkan pendalaman Bahasa Indonesia harus lebih ditekankan agar mengasah kemampuan siswa dalam berkomunikasi dan menghindari lahirnya siswa dengan kemampuan bahasa yang minim.

Kamus Besar Bahasa Indonesia menuliskan bahwa metode belajar diartikan sebagai cara yang teratur dan terpikir baik-baik untuk mencapai maksud dan tujuan tertentu. Winarno Surakhman dalam (Utarya, 2010), menuliskan bahwa metode belajar adalah cara utama yang digunakan untuk mencapai suatu tujuan tertentu. Dalam metode belajar yang digunakan dalam pembelajaran Bahasa Indonesia pada SD 011 Titian Resak Kecamatan Seberida siswa mendapatkan fasilitas, penjelasan, materi, dan tugas yang sama, tetapi mempunyai perbedaan hasil belajarnya. Jika siswa mengikuti pembelajaran dengan baik tanpa ada hambatan atau kesulitan dalam belajarnya, maka akan memperoleh prestasi atau hasil belajar yang baik. Namun, ketika siswa mengalami hambatan atau kesulitan dalam proses pembelajaran, maka prestasi tidak akan sesuai dengan yang diharapkan. Sehingga perlu banyak dilakukan pembiasaan atau kegiatan untuk mengasah kemampuan komunikasi, salah satunya adalah dengan metode diskusi. Diskusi merupakan siasat untuk menyampaikan bahan pelajaran yang melibatkan siswa secara aktif untuk membicarakan dan menemukan alternatif pemecahan suatu topik bahasan (Wina Sanjaya, 2006)

Pembelajaran dengan metode diskusi merupakan salah satu metode yang menarik dan inovatif yang dapat meningkatkan ketertarikan dan juga konsentrasi siswa terhadap suatu topik. Pembelajaran yang menarik sendiri dapat menumbuhkan minat untuk belajar dan memberikan perhatian yang lebih terhadap pelajaran. Siswa yang memiliki minat terhadap subjek tertentu cenderung untuk memberikan perhatian yang lebih besar terhadap subjek tersebut (Slameto, 2003) sehingga nantinya perhatian tersebut dapat membantu siswa dalam menerima informasi dari guru dengan kualitas yang lebih baik. Dalam metode ini guru mendorong proses pelibatan dua atau lebih orang peserta untuk saling berinteraksi (bertukar pendapat), atau saling mempertahankan pendapat dalam pemecahan masalah sehingga didapatkan kesepakatan di antara mereka (Bunga, 2016). Pembelajaran yang menggunakan metode diskusi merupakan pembelajaran yang bersifat interaktif (Putriyanti, 2017)

Melihat kenyataan adanya kemungkinan kesenjangan komunikasi pada masa pandemi ini, penulis ingin meningkatkan hasil pembelajaran Bahasa Indonesia menggunakan metode diskusi yang dilakukan secara daring sebagai praktik langsung dari teori Bahasa Indonesia itu sendiri. Dengan menggunakan metode ini diharapkan akan terjadi dialog dua arah antar siswa. Dialog tersebut akan terjadi tutor sebaya, di mana siswa yang kemampuannya rendah akan mendapat bantuan dari siswa yang mempunyai kemampuan tinggi.

\section{METODE PENELITIAN}

Metode penelitian yang digunakan adalah metode deskriptif yang mendeskripsikan bagaimana penerapan metode diskusi selama menjalani pembelajaran dalam jaringan saat masa pandemi Covid-19 ini dan dilanjutkan dengan analisis data menggunakan uji perbandingan ganda (paired sampel t-test) untuk membandingkan apakah terdapat perubahan yang signifikan sebelum dan sesudah dilakukannya metode diskusi.

Test dua sampel yang berpasangan (paired simple $t$ test) diartikan sebagai sebuah sampel dengan subjek yang sama namun mengalami dua perlakuan atau pengukuran yang 
berbeda. Sama seperti analisis sebelumnya uji ini bertujuan untuk mengetahui apakah dua sampel berpasangan mempunyai nilai rata-rata yang sama atau tidak.Objek penelitian ini yaitu metode diskusi yang dapat dijadikan salah satu metode untuk meningkatkan pemahaman siswa. Sumber data pada artikel ini berasal dari hasil observasi penilaian hasil belajar siswa SDN 011 Titian Resak.

\section{HASIL DAN PEMBAHASAN}

Dalam masa pandemi yang mengharuskan berkomunikasi secara virtual membutuhkan upaya yang lebih dalam membuat siswa memahami materi yang disampaikan, salah satunya ialah mata pelajaran Bahasa Indonesia yang merupakan jembatan untuk ilmu lainnya. Sehingga siswa perlu dipancing untuk terbiasa menggunakan Bahasa Indonesia yang baik dan benar, salah satu metode yang dapat digunakan adalah metode diskusi.

Metode diskusi memiliki kekuatan untuk mendorong siswa untuk menggali informasi dan membuatnya menjadi sebuah ide pikiran yang diperkaya, memotivasi antar lawan diskusi secara sehat, menjali hubungan yang erat dengan teman sebaya terutama di masa pandemi yang membuat siswa jarang berkomunikasi dan dekat dengan teman sebaya, juga dapat meningkatkan pemahaman terhadap diri sendiri dan orang lain.

Kelebihan metode ini adalah dapat mengasah siswa kritis terhadap suatu informasi, membiasakan berbahasa yang baik dan benar, melatih keberanian diri dalam berbicara di hadapan orang lain, mengajarkan prinsip menghargai pendapat dan mendengarkan orang lain, memupuk rasa tanggung jawab terhadap perkataan yang dilontarkan siswa atau keputusan yang dibuat, mengembangkan rasa solidaritas, dan sebagai latihan berkomunikasi dengan sistematis dan logis.

Selain itu, metode ini juga memiliki beberapa kekurangan antara lain memerlukan waktu yang cukup banyak dengan suasana yang nyaman, guru harus dapat mengarahkan ruang pembicaraan saat dirasa diskusi sudah berbelit-belit dan melenceng dari topik utama, adanya kemungkinan siswa yang tidak aktif menarik diri karena merasa terasingkan oleh siswa yang aktif (diskusi didominasi orang tertentu), serta adanya kemungkinan perkelaian di luar jam pelajaran antar siswa yang memiliki argumen bertentangan.

Analisis perbandingan menggunakan analisis paired sampel $t$ test merupakan analisis untuk mengetahui apakan terdapat perbedaan antara nilai sebelum dan sesudah dilakukannya penerapan metode diskusi di kalangan siswa sebagai salah satu upaya untuk memaksimalkan pemahaman siswa terhadap pelajaran Bahasa Indonesia di SDN 011 Titian Resak. Siklus I dilakukan sebelum diterapkannya metode diskusi yaitu pada Agustus 2019 dengan mengerjakan hasil evaluasi materi LKS 1. Kemudian siklus II dilakukan setelah penerapan metode diskusi pada September 2019 dengan mengerjakan hasil evaluasi materi LKS 2.

Pertama dapat dilihat gambaran umum perkembangan nilai siswa sebelum dan sesudah dilakukannya metode diskusi.

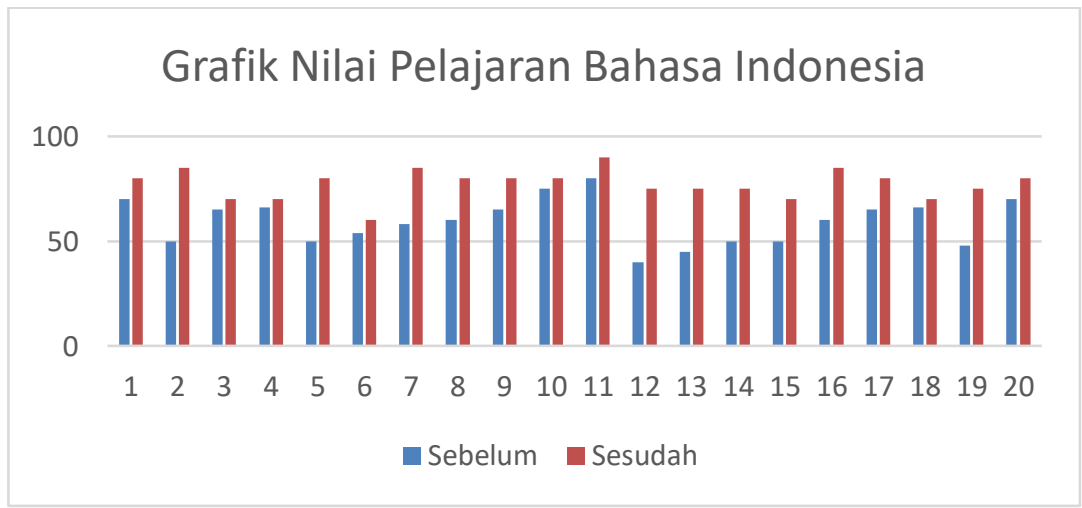

\section{Gambar 1. Grafik Nilai Siswa}

Berdasarkan grafik di atas nilai sesudah diterapkan metode diskusi lebih tinggi dari sebelum metode diskusi. Dengan ukuran pemusatan data sebelum adalah sebesar 59.35 dan sesudah adalah 77.25 dan ukuran penyebaran datanya adalah sebesar 10.69321 untuk sebelum diskusi 
dan 6.972691 untuk sesudah diskusi hal ini menggambarkan bahwa data pada sebelum dilakukan diskusi lebih beragam dibandingkan dengan setelah diskusi.

Tabel 1. Data Nilai Siswa

\begin{tabular}{|c|c|c|}
\hline No & Sebelum & Sesudah \\
\hline 1 & 70 & 80 \\
\hline 2 & 50 & 85 \\
\hline 3 & 65 & 70 \\
\hline 4 & 66 & 70 \\
\hline 5 & 50 & 80 \\
\hline 6 & 54 & 60 \\
\hline 7 & 58 & 85 \\
\hline 8 & 60 & 80 \\
\hline 9 & 65 & 80 \\
\hline 10 & 75 & 80 \\
\hline 11 & 80 & 90 \\
\hline 12 & 40 & 75 \\
\hline 13 & 45 & 75 \\
\hline 14 & 50 & 75 \\
\hline 15 & 50 & 70 \\
\hline 16 & 60 & 85 \\
\hline 17 & 65 & 80 \\
\hline 18 & 66 & 70 \\
\hline 19 & 48 & 75 \\
\hline 20 & 70 & 80 \\
\hline & & \\
\hline
\end{tabular}

Paired T-Test merupakan bagian dari analisis parametrik sehingga hal yang harus diperhatikan pertama kali adalah datanya harus berdistribusi normal. Tentu untuk mengetahui apakah data yang digunakan telah berdistribusi normal atau belum maka harus dilakukan uji kenormalan atau uji normalitas terlebih dahulu. Pada pengujian normalitas akan menggunakan metode shapiro test karena data berjumlah kurang dari 30. Dengan $\mathrm{H} 0$ adalah data berdistribusi normal dan $\mathrm{Ha}$ adalah data tidak berdistribusi normal kemudian nilai $p$-value akan dibandingkan dengan tingkat signifikansi yaitu sebesar 0.05. Di mana akan H0 dapat ditolak jika $p$-value melebihi 0.05 .

Tabel 2. Uji Normalitas

\begin{tabular}{|c|c|c|c|l|}
\hline Variabel & p-value & Tanda & Keputusan & Kesimpulan \\
\hline Sebelum & 0.6731 & $>$ & Gagal Tolak H0 & $\begin{array}{l}\text { Data } \\
\text { berdistribusi } \\
\text { normal }\end{array}$ \\
\hline Sesudah & 0.208 & $>$ & Gagal Tolak H0 & $\begin{array}{l}\text { Data } \\
\text { berdistribusi } \\
\text { normal }\end{array}$ \\
\hline
\end{tabular}

Selanjutnya akan dilakukan uji perbandingan paired simple t test untuk mengetahui apakah metode diskusi menaikkan nilai siswa atau tidak. H0 yang digunakan adalah rata-rata Sesudah metode diskusi $\leq$ Sebelum metode diskusi dan Ha adalah rata-rata Sesudah metode diskusi dilakukan > Sebelum metode diskusi dilakukan. Di mana nilai $p$-value akan dibandingkan dengan tingkat signifikansi yaitu sebesar 0.05. Di mana akan H0 dapat ditolak jika $p$-value melebihi 0.05 . 
Tabel 3. Uji Perbandingan

\begin{tabular}{|c|c|c|c|c|}
\hline Metode & p-value & Tanda & Keputusan & Kesimpulan \\
\hline Paired t test & $5.135 \times 10^{-7}$ & $<$ & Tolak H0 & Nilai sesudah \\
& & & & metode diskusi \\
& & & & $\begin{array}{l}\text { dari sebelum } \\
\text { metode diskusi }\end{array}$ \\
\hline
\end{tabular}

Berdasarkan hasil analisis didapatkan hasil bahwa nilai p-value lebih kecil dari 0.05 sehingga keputusannya adalah menolak $\mathrm{H} 0$ yang artinya nilai rata-rata sesudah metode diskusi lebih baik atau lebih tinggi dari nilai rata-rata sebelum metode diskusi dilakukan. Hal ini mengartikan bahwa metode diskusi dengan segala kelebihannya baik digunakan untuk meningkatkan pemahaman siswa terhadap materi pembelajaran Bahasa Indonesia.

Pada penelitian sebelumnya juga menghasilkan hasil yang sama di mana metode diskusi memiliki dampak yang signifikan terhadap perkembangan nilai siswa. Penelitian pertama dilakukan oleh Ch. Catur Putriyanti dan Febianus Fensi pada tahun 2017 dengan judul Penerapan Metode Diskusi Kelompok untuk Meningkatkan Hasil Belajar Siswa pada Mata Pelajaran IPS di Kelas IX SMP Santa Maria Monica, Bekasi Timur. Didapatkan hasil bahwa diskusi kelompok mendorong peserta didik terlibat dalam proses belajar bersama teman. Teman sebaya tersebut menyebabkan meningkatnya minat terhadap topik tertentu dan meningkatnya minat tersebut ikut meningkatkan hasil belajar yang diperoleh peserta didik. Metode diskusi terbukti berhasil untuk meningkatkan hasil peserta didik kelas IX SMP Santa Maria Monica, hal ini terlihat dari menurunnya jumlah peserta didik yang memperoleh nilai di bawah KKM. Selanjutnya adalah penelitian yang dilakukan oleh Nengah Kelirik pada tahun 2018 dengan judul penelitian Penerapan Metode Diskusi Kelompok untuk Meningkatkan Hasil Belajar IPA di Sekolah Dasar Negeri 1 Sukadana. Tujuan dari penelitian ini adalah meningkatkan hasil belajar IPA siswa kelas V SD Negeri 1 Sukadana melalui metode diskusi kelompok hingga didapatkan kesimpulan bahwa nilai rata-rata hasil belajar siswa pada refleksi awal sebesar 68,39 meningkat 1,3 pada siklus I menjadi 69,68 kemudian meningkat sebesar 11,61 menjadi 81,29 pada siklus II. Daya serap meningkat 1,3\% dari 68,39\% pada refleksi awal menjadi 69,68\% pada siklus I dan mengalami peningkatan sebesar $11,61 \%$ menjadi $81,29 \%$ pada siklus II. Ketuntasan belajar secara klasikal juga meningkat 9,7\% dari refleksi awal sebesar 54,84\% menjadi $64,52 \%$ dan sebesar $35,48 \%$ sehingga menjadi $100 \%$ pada siklus II. Penerapan metode diskusi kelompok telah berhasil meningkatkan hasil belajar IPA siswa kelas V SD Negeri 1 Sukadana.

\section{KESIMPULAN}

Berdasarkan hasil perbandingan yang dilakukan dengan analisis paired sampel t test didapatkan kesimpulan bahwa nilai setelah diskusi lebih tinggi dan berbeda signifikan dengan nilai sebelum diterapkannya metode diskusi pada siswa SDN 011 Titian Resak. Sehingga terbukti bahwa metode diskusi sangat efektif dalam meningkatkan pemahaman siswa SDN 011 Titian Resak dalam memahami materi pelajaran Bahasa Indonesia.

\section{DAFTAR PUSTAKA}

Bunga, Destri Nugria. (2016). Minat Mahasiswa Tentang Penerapan Metode Diskusi dalam Proses Pembelajaran pada Program Studi Pendidikan Administrasi Perkantoran Fakultasilmu Sosial Universitas Negeri Makassar. Jurnal Office. Vol 2 (2).

Ermi, Netti. (2015). Penggunaan Metode Diskusi untuk Meningkatkan Hasil Belajar Materi Perubahan Sosial pada Siswa Kelas XII SMA Negeri 4 Pekanbaru. Jurnal Sorot. Vol 10(2), pp: 155-168.

Kelirik, Nengah. (2018). Penerapan Metode Diskusi Kelompok untuk Meningkatkan Hasil Belajar Ipa Di Sekolah Dasar Negeri 1 Sukadana. Jurnal IKA. Vol 16 (1). 
Putriyanti, Ch. Catur. (2017). Penerapan Metode Diskusi Kelompok untuk Meningkatkan Hasil Belajar Siswa pada Mata Pelajaran IPS di Kelas IX SMP Santa Maria Monica, Bekasi Timur. Jurnal Psibematika. Vol 10(2).

Slameto. (2003). Belajar dan Faktor-faktor yang Mempengaruhinya. Jakarta: PT. Rineka Cipta. Utarya. (2010). Peningkatan prestasi belajar IPS melalui metode diskusi kelompok pada siswa kelas IV SD Negeri 1 Sumur Musuk. Skripsi tidak diterbitkan. Universitas Sebelas Maret: Surakarta.

Wina, Sanjaya. (2010). Strategi Pembelajaran Berorientasi Estándar Proses Pendidikan. Jakarta: Kencana. 